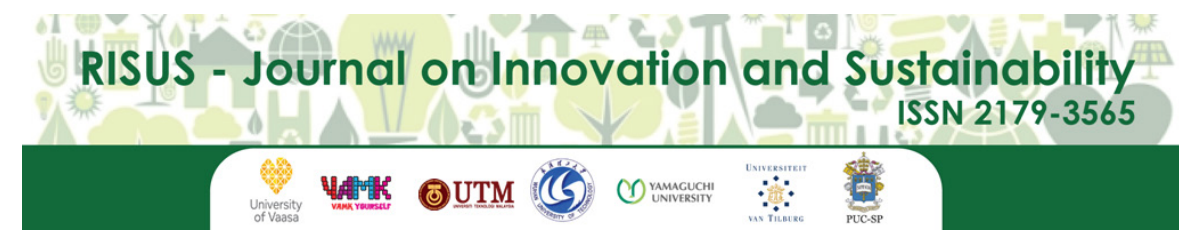

RISUS - Journal on Innovation and Sustainability volume 9, número 2 - 2018

ISSN: $2179-3565$

Editor Científico: Arnoldo José de Hoyos Guevara Editora Assistente: Lívia Lopes Aguiar

Avaliação: Melhores práticas editoriais da ANPAD

\title{
EMPLOYEE EMPOWERMENT, TRUST, AND INNOVATIVE BEHAVIOR: TESTING A PATH MODEL
}

\begin{abstract}
Empoderamento dos colaboradores, confiança e comportamento inovador: testando um modelo de Path Analysis
\end{abstract}

\author{
Muhammad Anwar ul Haq ${ }^{1}$, Muhammad Usman², Shaista Khalid ${ }^{3}$ \\ ${ }^{1}$ Department of Management Sciences, University of Gujrat, Pakistan. \\ ${ }^{2}$ Department of Commerce and Management Sciences, University of Malakand, Pakistan. \\ ${ }^{3}$ Department of Education, University of Sargodha, Pakistan. \\ E-mail: aayhaq@yahoo.com; mohdusman1@hotmail.com; shaistakhalid@gmail.com
}

\begin{abstract}
The motive behind this paper was mainly to uncover the trust mechanism in the field of employee empowerment and innovative behavior. It was hypothesized that structural empowerment and psychological empowerment will influence innovative behavior. Empowerment was also hypothesized to influence trust. We also posited that trust will act a mediator. Data came from 410 respondents employed in the manufacturing, banking, cement, telecommunication sector in Pakistan. Regression analysis proved our hypothesis. In the end, suggestions and recommendations have been given.
\end{abstract}

Key words: empowerment, trust, innovative behavior

Resumo: O objetivo deste trabalho foi principalmente para tentar descobrir o mecanismo de confiança no campo do empoderamento dos funcionários ou colaboradores e o comportamento inovador, a partir da ideia de que o empoderamento estrutural e o empoderamento psicológico influenciarão o comportamento inovador. O empoderamento também se considera como um fator que pode influenciar a confiança, por atuar como um mediador. Os dados vieram de 410 entrevistados empregados no setor manufatureiro, bancário, de cimento e telecomunicações no Paquistão. A análise de regressão utilizando Path Analysis verificou a hipótese. No final, sugestões e recomendações foram dadas.

Palavras chave: empoderamento, confiança, comportamento inovador.

\author{
Recebido em: 08/07/2017
}

Aceito em: 01/06/2018 


\section{INTRODUCTION}

Innovation is at the core of organizational success (Thornhill, 2006) and this role has been empirically evidenced also (Martins \& Terblanche, 2003). The organizations rely on their best human capital in order to produce innovations. These are the employee who offer creative ideas which the organizations materialize into innovations and turn into their competitive edge (Patterson, Kerrin, \& Gatto-Roissard, 2009). Given the importance of innovative behavior for organizations, understanding the mechanisms involved in innovative behavior is an important area of study. Strictly speaking, in the recent turbulent economic times, gaining innovative edge is also imperative to survival of an organization.

Innovative behavior is intentionally introducing new ideas, services, products, processes, and/ or procedures in the workplace by an employee. These may be limited to an employee's own unit, may relate to a group or an organization as a whole (West \& Farr, 1990). Innovative behavior is also "opportunity exploration, idea generation, idea promotion, and the implementation of ideas" (Scott \& Bruce, 1994). Innovative employees look for opportunities to give novel solutions to. They propagate their ideas effectively. They build support for the implementation of those ideas. The conclude with idea implementation which also includes ideas testing, modification of the outcomes, and finally the commercialization (Dörner, 2012). According to Åmo (2006), innovativeness also includes modification of routines, simplification of work, service improvement, or giving new offers to customers. The innovative workers engage in any one or many of earlier mentioned activities at a time (Scott \& Bruce, 1994). Yuan (2012) recalls that element of "newness" in all the descriptions of innovation does not necessarily entail that the idea has to be new for the world as a whole. Innovativeness implies anything that is novel for a particular context of the organization or individual. Moreover, innovativeness ranges from radical innovations to incremental (Axtell et al., 2000), from administrative to technological (Van de Ven, 1986), and from soft to hard.

Though, empowerment has already been found to relate with innovativeness, yet mediating mechanisms in this realm remain to chart out. In this study, we test a path model involving organizational trust as mediator. Moreover, the studies from a developing context are also lacking in the literature. We use the data from manufacturing sector of Pakistan.

\section{LITERATURE REVIEW AND HYPOTHESES}

\section{Empowerment and innovative behavior}

Power refers to the "ability to get things done, to mobilize resources, to obtain, and use whatever a person needs to achieve the goals of the organization" (Kanter, 1993). The level of control which employees can exerciser over their work is linked with their performance. Power in formal connotation, means the decision-making discretion. Alternatively, informal power is related with support and communication in the workplace (Kanter, 1993).

Employee empowerment is mostly view from two perspectives: structural, and psychological. Employees have structurally empowerment if they can approach information, support, resources, and chances for learning and growth (Laschinger, Finegan, Shamian, \& Wilk, 2004). Access to information occurs when employees have knowledge, both formal and informal, for the effective performance of their jobs. Likewise, they should also have technical knowledge and expertise and an understanding of decision and policies of organization. Access to support means receiving performance feedback from fellows, either superiors or subordinates, in the organization. Access to 
resources involves employees' ability to monetary resources, and implements required to complete their task (Kanter, 1993). The focus of structural empowerment is employee's actual interpretation of the work conditions (Laschinger et al., 2004). Psychological empowerment pertains to employees' psychological state of being empowered and having a feeling of control over their job (Spreitzer, 1995). In order to make psychological empowerment comprehend-able, Spreitzer (1995) cracks it into four dimensions: "meaning, competence, self-determination, and impact". Meaning refers to the correspondence between beliefs, values, behaviors, and requirement of job of an employee. Competence is confidence over one's abilities to do the job. Self-determination entails a state of mind that one has control over one's work. Impact is the feeling that one able to influence organizational outcomes. A difference to be noted between the two perspectives is that the former is the perception about the conditions empowering the employees in the workplace, whereas, the latter is the psychological reaction to such conditions (Laschinger et al., 2004).

Empowered employees offer novel ideas which otherwise are impossible. Empowerment facilitates employees to engage in "trial-and-error", a vital requirement in the process of innovation (Ramamoorthy, Flood, Slattery, \& Sardessai, 2005). Empowerment allows experimentation and unconventional techniques which land into innovations and inspire original ideas (De Spiegelaere, Gyes, \& Hootegem, 2014). Roberg (2007) shows that empowerment is related innovative behavior. Hence, we hypothesize that:

H1: Structural empowerment influences innovative behavior positively.

H2: Psychological empowerment influences innovative behavior positively.

\section{Empowerment and trust}

According to Mayer, Davis, and Schoorman (1995), trust occurs when party A is willingly vulnerable to the actions of party B while expecting that party B will perform an act important to the party A, regardless of party A's ability to control the action of party B. Party A would be trustor, whereas party B would be trustee in such situation. In essence, the trustor takes the risk to pose confidence over the trustee, and the trustor is vulnerable in such a way that he/she may lose something (Schoorman, Mayer, \& Davis, 2007) in this interpersonal transaction (Bhattacharya, Devinney, \& Pillutla, 1998). In organizations, employees do their tasks on the trust of supervisor (Bhattacharya et al., 1998). Trust may be either vertical or lateral. Vertical trust denotes employees' trust on their supervisor. Lateral trust entails trust between peer at a similar hierarchy in organization (Stull \& Aram, 2010).

According to Laschinger and Finegan (2004), structural empowerment predicts trust in management. The environment which provides structural conditions to managers is responded by employees through increased trust in their manager. Laschinger, Finegan, and Shamian (2001) also held that structural empowerment develops a sense of psychological empowerment among employees which in turn builds trust of employees over their supervisor and organization. Moye, Henkin, and Egley (2005) found that empowered employees will function to eradicate mistrust between supervisor and employees. Moye and Henkin (2006) advise the way manager can improve trust among subordinates. They argue that when manager decrease dependence on control and monitoring mechanisms, employees feel empowered. They signal employees about the trusting behavior of bosses. Hence, empowerment and trust may be thought the relate positively.

H3: Structural empowerment influences trust positively.

H4: Psychological empowerment influences trust positively. 


\section{Trust and innovative behavior}

Carmeli and Spreitzer (2009) have empirically connected trust with innovative behavior. They argue that trust creates a psychological contract between employer and employee. Psychological contract augments relationships with organizational peers. This relational connectivity affects thriving among individuals. The connectivity in turn, enhances employee innovative behaviors in the workplace.

Clegg, Unsworth, Epitropaki, and Parker (2002) has explained the role of trust in terms of; trust that heard and trust that benefit, in the process of innovation. They explicate that employees' trust that their organization will listen to their suggestions will have positive effect on idea implementation aspect of innovative behavior. In other words, the more the employees have belief that their suggestions are taken considerately, they will argue for the application of their ideas. Alternatively, the "trust that benefit" will operates at personal level. It is linked with the perception of outcomes and rewards. The more the employee have trust that their effort will bring rewards, the more they will engage in innovative behavior (Clegg et al., 2002).

Lastly, we also hunch that trust will intervene the connection between employee empowerment and innovative behavior. Empowerment develops a psychological feeling among employees that their organization rests trust upon them. One such feeling is developed; employees more likely go beyond the roles described for them. They engage in such behaviors which uniquely advantage their organization. Off such behaviors, innovative behavior is also a common behavior. Hence, we hypothesize that

H5: Trust will positively influence innovative behavior

H6: Trust will mediate the influence of structural empowerment of employees on innovative behavior.

H7: Trust will mediate the influence of psychological empowerment of employees on innova tive behavior.

\section{METHODOLOGY}

\section{PARTICIPANTS AND PROCEDURES}

The sample for this study was drawn from the manufacturing sector of Pakistan. In order to enhance the representation, we used a multistage sampling with a unique criterion at each stage. At the first stage, all the companies having an employee strength of at least 300 were selected from all provinces. Next, we randomly choose the companies in such a way that at least 5 companies are selected in each industry, that is, manufacturing, banking, textile, cement, and fertilizer.

We sent the questionnaire to at least 50 employees in every companies selected in each industry. Questionnaires were sent both by postage and using google forms. By both ways, 645 questionnaires were circulated across all the companies. The number of returned responses were 410, with response rate of 63 percent. After sorting the questionnaires for usability, 8 were discarded for lack of information. Hence the total usable sample was 402 responses. The sample comprised of 57\% male and $43 \%$ female respondents. The average age was 29 years. 


\section{Measures}

Innovative behavior was measured using the instrument of De Jong and Den Hartog (2010). It was measured on a behavioral frequency scale $(1=$ rarely, $6=$ often).

Empowerment was measured across two dimensions: structural empowerment, psychological empowerment. The instrument on Conditions for Work Effectiveness Questionnaire - II (Laschinger, Finegan, Shamian, \& Wilk, 2001) was used for structural empowerment. The factors of structural empowerment were access to opportunity, information, support and resources. For psychological empowerment, we used the scale by Spreitzer (1995). It was operationally defined in terms of meaning, competence, self-determination, and impact.

Trust was measured with the help of scale by Mayer and Gavin (2005). The scale consists of 10-items on 5-point Likert scale.

\section{Control variables}

Gender: the effect of gender was also controlled for spuriousness of inference. However, in this era, we may no longer assume any differences between males and females because now females have improved access to opportunities.

Age: was used age as control variable. It is generally observed that people usually tend to be more innovative at younger age because they are enthusiastic and have fresh ideas.

Education: was also used as a control variable.

\section{DATAANALYSIS}

\section{Descriptive results}

The table below (see Table 1) shows presents a summary of descriptive statistics. All the correlations were significant $(\mathrm{p}<.001)$. For assessing convergent validity, average variance extracted (AVE) were calculated. All values were above 0.5 . The constructs also had discriminant validity since maximum shared variance (squared correlations) were below AVE (Fornell \& Larcker, 1981).

Table 1: Descriptive results

\begin{tabular}{|c|c|c|c|c|c|c|c|}
\hline Constructs & Mean & SD & AVE & 1 & 2 & 3 & 4 \\
\hline 1. IB & 3.413 & 1.703 & 0.710 & $(0.251)$ & & & \\
\hline 2. $\mathrm{SE}$ & 3.761 & 1.613 & 0.753 & 0.413 & $(0.321)$ & & \\
\hline 3. $\mathrm{PE}$ & 2.343 & 1.530 & 0.792 & 0.501 & 0.567 & $(0.321)$ & \\
\hline 4. TRUST & 3.127 & 1.731 & 0.776 & 0.492 & 0.478 & .541 & $(0.292)$ \\
\hline
\end{tabular}

IB=Innovative Behavior, $\mathrm{SE}=$ Structural Empowerment, $\mathrm{PE}=$ Psychological Empowerment, $\mathrm{AVE}=$ Average variance extracted,

\section{Confirmatory factor analysis}

The hypothesized measurement model was test using AMOS. In the first run, the model fit values showed that model was fit $\left(\chi^{2} / \mathrm{df}=2.981, \mathrm{CFI}=0.971, \mathrm{TLI}=0.987 \mathrm{RMSEA}=0.31\right)$. A second model was also test to check if there were any method biases (Podsakoff, MacKenzie, Lee, \& Podsakoff, 2003) whether there exist any alternative explanations of proposed measurement model. In this model, all the variables were loaded on a single factor. The model fit $\left(\chi^{2} / \mathrm{df}=4.981, \mathrm{CFI}=0.671, \mathrm{TLI}=0.787\right.$ RMSEA $=0.87$ ) was out of the suggested threshold (Hu \& Bentler, 1999). 


\section{Hypotheses testing}

We ran linear regression for testing hypotheses testing. It must be noted that we ran separate regression models for structural and psychological empowerment. Baron and Kenny (1986) procedure was used to examine the inter-mediation model. The table below (see Table 2) reports the result of hypotheses. H1 states the structural empowerment has positive influence on innovative behavior. The results of regression analysis provide the support $(\beta=0.405, \mathrm{p}<0.001)$. Similarly, in $\mathrm{H} 2$, psychological empowerment proved a positive predictor of innovative behavior as hypothesized $(\beta=0.517, \mathrm{p}<0.001)$. Next, we regressed trust structural empowerment and psychological empowerment respectively. The results were same as posited $(\beta=0.393 \mathrm{p}<0.001 ; \beta=0.418, \mathrm{p}<0.001)$. This also proved the second condition of mediation tested to be true. Third, we ran the model with trust as independent variable and innovative behavior as dependent variable. The hypothesis proved as proposed $(\beta=0.402, p<0.001)$. This also fulfilled the third condition of mediation. In the fourth and last step, we regressed the trust on structural empowerment, then trust on psychological empowerment and innovative behavior respectively. The results proved that fully mediated the effect of both structural empowerment and psychological empowerment separately on innovative behavior (see Table 2).

Table 2: Regression results

\begin{tabular}{|c|c|c|c|c|}
\hline Steps & Constructs & Standardized beta & Standard error & Adjusted $\mathbf{R}^{2}$ \\
\hline $\begin{array}{l}\text { Step I } \\
\text { Outcome }\end{array}$ & Innovative behavior & & & \\
\hline Predictor & $\begin{array}{l}\text { Structural empowerment } \\
\text { Psychological empowerment }\end{array}$ & $\begin{array}{l}.405^{* * *} \\
.517^{* * *}\end{array}$ & $\begin{array}{l}.031 \\
.027\end{array}$ & $\begin{array}{l}.367 \\
.436\end{array}$ \\
\hline $\begin{array}{l}\text { Step } 2 \\
\text { Outcome }\end{array}$ & Trust & & & \\
\hline Predictor & $\begin{array}{l}\text { Structural empowerment } \\
\text { Psychological empowerment }\end{array}$ & $\begin{array}{l}.393^{* * *} \\
.418^{* * *}\end{array}$ & $\begin{array}{l}.034 \\
.045\end{array}$ & $\begin{array}{l}.410 \\
.481\end{array}$ \\
\hline $\begin{array}{l}\text { Step } 3 \\
\text { Outcome }\end{array}$ & Innovative Behavior & & & \\
\hline $\begin{array}{l}\text { Predictor } \\
\text { Step } 4\end{array}$ & Trust & $.402 * * *$ & .071 & .383 \\
\hline Outcome & Innovative Behavior & & & \\
\hline Mediator & Trust & $306 * * * / 351 * * *$ & $.082 / .051$ & \\
\hline Predictor & $\begin{array}{l}\text { Structural Empowerment } \\
\text { Psychological Empowerment }\end{array}$ & $\begin{array}{l}385 * * * \\
.485 * * *\end{array}$ & $\begin{array}{l}.074 \\
.041\end{array}$ & $\begin{array}{l}.513 \\
.590\end{array}$ \\
\hline
\end{tabular}

\section{DISCUSSION AND CONCLUSION}

The results coincide with our underlying theoretical frameworks. This paper adds to literature by uncovering the trust mechanism in field of empowerment and innovative behavior. We advise the managers to be mindful of the fact of that employee empowerment is necessary for both trust and innovative behavior.

However, we remind that the cross-sectional studies lack the establishment of causality. Since, we also use cross-sectional data which may be a limitation for this study.

Further studies should be conducted with longitudinal design. Mixed methods may also bring in-depth conclusions. Across the occupation studies should also be conducted. 


\section{REFERENCES}

Åmo, B. (2006). Employee innovation behaviour in health care: the influence from management and colleagues. International Nursing Review, 53(3), 231-237.

Axtell, C. M., Holman, D. J., Unsworth, K. L., Wall, T. D., Waterson, P. E., \& Harrington, E. (2000). Shopfloor innovation: Facilitating the suggestion and implementation of ideas. Journal of occupational and organizational psychology, 73(3), 265-285.

Baron, R. M., \& Kenny, D. A. (1986). The moderator-mediator variable distinction in social psychological research: Conceptual, strategic, and statistical considerations. Journal of personality and social psychology, 51(6), 1173.

Bhattacharya, R., Devinney, T. M., \& Pillutla, M. M. (1998). A formal model of trust based on outcomes. Academy of management Review, 23(3), 459-472.

Carmeli, A., \& Spreitzer, G. M. (2009). Trust, connectivity, and thriving: Implications for innovative behaviors at work. The Journal of Creative Behavior, 43(3), 169-191.

Clegg, C., Unsworth, K., Epitropaki, O., \& Parker, G. (2002). Implicating trust in the innovation process $\dagger$. Journal of Occupational and Organizational Psychology, 75(4), 409-422.

De Jong, J., \& Den Hartog, D. (2010). Measuring innovative work behaviour. Creativity and Innovation Management, 19(1), 23-36.

De Spiegelaere, S., Gyes, G. V., \& Hootegem, G. V. (2014, 4-7 June). Different dimensions of Job Autonomy and Their Relation with Work Engagement \& Innovative Work Behaviour: The More the Merrier? Paper presented at the EURAM 2014, Valencia.

Dörner, N. (2012). Innovative Work Behavior: The Roles of Employee Expectations and Effects on Job Performance. University of St.Gallen, Bamberg

Fornell, C., \& Larcker, D. F. (1981). Evaluating structural equation models with unobservable variables and measurement error. Journal of marketing research, 39-50.

Hu, \& Bentler, P. M. (1999). Cutoff criteria for fit indexes in covariance structure analysis: Conventional criteria versus new alternatives. Structural equation modeling: a multidisciplinary journal, 6(1), 1-55.

Kanter, R. M. (1993). Men and Women of the Corporation: Basic books.

Laschinger, H. K. S., Finegan, J., \& Shamian, J. (2001). The impact of workplace empowerment, organizational trust on staff nurses' work satisfaction and organizational commitment. Health care management review, 26(3), 7-23. 
Laschinger, H. K. S., Finegan, J., Shamian, J., \& Wilk, P. (2001). Impact of structural and psychological empowerment on job strain in nursing work settings: expanding Kanter's model. Journal of nursing Administration, 31(5), 260-272.

Laschinger, H. K. S., \& Finegan, J. E. (2004). EMPOWERMENT, INTERACTIONAL JUSTICE, TRUST AND RESPECT: A NURSING RECRUITMENT AND RETENTION STRATEGY. Paper presented at the Academy of management proceedings.

Laschinger, H. K. S., Finegan, J. E., Shamian, J., \& Wilk, P. (2004). A longitudinal analysis of the impact of workplace empowerment on work satisfaction. Journal of Organizational Behavior, 25(4), $527-545$.

Martins, E., \& Terblanche, F. (2003). Building organisational culture that stimulates creativity and innovation. European Journal of Innovation Management, 6(1), 64-74.

Mayer, R. C., Davis, J. H., \& Schoorman, F. D. (1995). An integrative model of organizational trust. Academy of management Review, 20(3), 709-734.

Mayer, R. C., \& Gavin, M. B. (2005). Trust in management and performance: Who minds the shop while the employees watch the boss? Academy of Management Journal, 48(5), 874-888.

Moye, M. J., \& Henkin, A. B. (2006). Exploring associations between employee empowerment and interpersonal trust in managers. Journal of management development, 25(2), 101-117.

Moye, M. J., Henkin, A. B., \& Egley, R. J. (2005). Teacher-principal relationships: Exploring linkages between empowerment and interpersonal trust. Journal of Educational Administration, 43(3), 260277.

Patterson, F., Kerrin, M., \& Gatto-Roissard, G. (2009). Characteristics and behaviours of innovative people in organisations. Literature Review prepared for the NESTA Policy \& Research Unit, 1-63.

Podsakoff, P. M., MacKenzie, S. B., Lee, J.-Y., \& Podsakoff, N. P. (2003). Common method biases in behavioral research: a critical review of the literature and recommended remedies. Journal of applied psychology, 88(5), 879.

Ramamoorthy, N., Flood, P. C., Slattery, T., \& Sardessai, R. (2005). Determinants of innovative work behaviour: Development and test of an integrated model. Creativity and Innovation Management, $14(2), 142-150$.

Roberg, L. C. (2007). Organizational empowerment and hardiness as predictors of innovativeness. (Master's Thesis), San Jose State University, San Jose. (3436) 
Schoorman, F. D., Mayer, R. C., \& Davis, J. H. (2007). An Integrative Model of Organizational Trust: Past, Present, and Future. Academy of management Review, 32(2), 344-354. doi: 10.5465/ amr.2007.24348410

Scott, S. G., \& Bruce, R. A. (1994). Determinants of innovative behavior: A path model of individual innovation in the workplace. Academy of management journal, 37(3), 580-607.

Spreitzer, G. M. (1995). Psychological empowerment in the workplace: Dimensions, measurement, and validation. Academy of Management Journal, 38(5), 1442-1465.

Stull, M., \& Aram, J. D. (2010). Exploring trust as an influencing mechanism of intrapreneurship. International Journal of Management and Marketing Research, 3(3), 17-38.

Thornhill, S. (2006). Knowledge, innovation and firm performance in high-and low-technology regimes. Journal of business venturing, 21(5), 687-703.

Van de Ven, A. H. (1986). Central problems in the management of innovation. Management science, $32(5), 590-607$.

West, M. A., \& Farr, J. L. (1990). Innovation and creativity at work: Psychological and organizational strategies: John Wiley \& Sons.

Yuan, F. (2012). Individual innovation in the workplace: The role of performance and image outcome expectations. Texas A\&M University. 